University of Rhode Island

DigitalCommons@URI

Open Access Master's Theses

1992

\title{
Equity Lending Practices and Home Mortgage Foreclosure in Selected Boston Inner-City Neighborhoods
}

Julie Vel Ross

University of Rhode Island

Follow this and additional works at: https://digitalcommons.uri.edu/theses

\section{Recommended Citation}

Vel Ross, Julie, "Equity Lending Practices and Home Mortgage Foreclosure in Selected Boston Inner-City Neighborhoods" (1992). Open Access Master's Theses. Paper 753.

https://digitalcommons.uri.edu/theses/753

This Thesis is brought to you for free and open access by DigitalCommons@URI. It has been accepted for inclusion in Open Access Master's Theses by an authorized administrator of DigitalCommons@URI. For more information, please contact digitalcommons-group@uri.edu. 
EQUITY LENDING PRACTICES AND

HOME MORTGAGE FORECLOSURE IN SELECTED

BOSTON INNER-CITY NEIGHBORHOODS

BY

JULIE VEL ROSS

\author{
A RESEARCH PROJECT SUBMITTED IN \\ PARTIAL FULFILLMENT OF THE REQUIREMENTS \\ FOR THE DEGREE OF MASTER OF \\ COMIUNITY PLANNING \\ UNIVERSITY OF RHODE ISLAND \\ 1992
}




\section{MASTER OF COMMNITY PLANNING}

\section{RESEARCH PROJECT}

OF

JULIE VEL ROSS

Approved:

Major Professor

Magan s Aman

Acknowledged:

Director

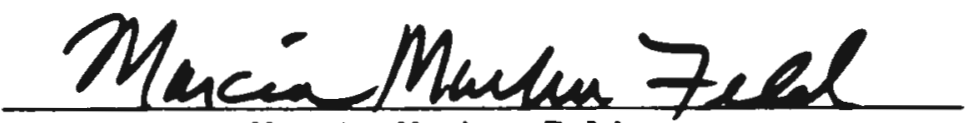

Marcia Marker Feld 


\section{ABSTRACT}

The purpose of this research project is to examine the equity lending practices of unregulated mortgage companies in Boston, Massachusetts from 1985 to 1990. The scope of the inquiry is limited to the lending practices by regulated banks and unregulated mortgage companies in Roxbury, Dorchester and Mattapan from 1985 to 1990. The research is done in response to the so-called second mortgage scam that affected minority residents in Roxbury, Dorchester and Mattapan.

To review these lending practices, four major questions are answered in this report. The questions are:

1) What are the lending patterns of Boston's major banks in Roxbury, Dorchester and Mattapan?

2) What finance structure enables unregulated mortgage companies to operate?

3) Who are the unregulated lenders in violation of established lending standards, and in what neighborhoods do they operate?

4) What efforts are being made at a city and state level to promote industry standards and prevent future foreclosures?

The research Indicates that Boston's regulated banks have redlined the areas of Roxbury, Dorchester and Mattapan, creating a demand for home mortgage and home improvement financing that was met by unregulated lenders. Some of the unregulated mortgage companies, particularly the Resource Companies, have packaged loan products that are very burdensome to the borrowers. The consequence to homeowners for borrowing from these companies was often foreclosure.

The key findings of this report are as follows:

- Boston's major banks have redlined Roxbury, Dorchester and Mattapan. 
- There was a disproportionate amount of loans contracted by homeowners with unregulated mortgage companies in Roxbury, Dorchester and Mattapan.

- Available information on interest rates and terms of loans from some unregulated mortgage companies operating in Roxbury, Dorchester and Kattapan were usurious (in excess of 30-percent).

- The foreclosure rate on properties with a mortgage company claim was 42.2 percent. Another 27.9 percent were at risk of foreclosure. These figures are based on the review of Suffolk County Registry of Deeds records of 660 properties in Roxbury, Dorchester and Mattapan.

- This practice cheats the homeowners of the equity they have built in their homes, and has a destabilizing effect on the neighborhoods.

City officials and community leaders are seeking remedies to the situation. Their efforts included regulating mortgage companies in Massachusetts as of January 1, 1992; imposing a moratorium on foreclosures to provide an opportunity to review the loan agreements; and establishing a multi-million fund for the purposes of providing home mortgage and home improvement financing in Roxbury, Dorchester and Mattapan.

While these remedies provide short-term solutions to the problem, the structure of the banking industry might promote such lending practices over the long-term. Long-term solutions, such as strict enforcement of the Community Reinvestment Act, need to be addressed to prevent this situation in the future. 


\section{ACRNOWLEDGEMENTS}

This author wishes to thank Bruce Marks, Executive Director of the Union Neighborhood Assistance Corporation, for providing his research for this report.

Additionally, the author wishes to thank Professor Marjorie Jensen for her support and guidance through this masters research project.

Finally, thanks to Barry, who thinks he bought me books and sent me to school, and to Grandma, who really did. 
TABLE OF CONTENTS

ABSTRACT

ACRNOWLEDGEYENTS

iv

CHAPTER ONE: INTRODUCTION .................... 1

INTRODUCTION ....................... 1

Statement of Purpose (2); Major Questions (2);

Objectives of the Research (3); Organization (4);

Methodology (4); Data Sources (4)

BACKGROUND

The Worst Consequence, Foreclosure (8)

SUMMARY

CHAPTER TWO: SELECTED NEIGHBORHOOD CHARACTERISTICS . . . . . . . . 9

NEIGHBORHOOD CHARACTERISTICS . . . . . . . . . . . . . 10

Data Sources (10); Neighborhoods, Median Incomes, and

Populations (10)

SUMMARY OF NEIGHBORHOOD CHARACTERISTICS . . . . . . . . 12

CHAPTER THREE: LENDING PRACTICES OF

BOSTON'S MAJOR BANRS ......... 13

BANRING PRACTICES: REDLINING IN BOSTON . . . . . . . . . 14

INTRODUCTION ...................... 14

Section One, Redlining .. . . . . . . . . . . . . 14

The Prevalence of Redlining Over Time (15); The

Transition of Nelghborhoods (15); Fundamental Causes

of Housing Deterioration (16)

Section Two, Evidence of Redlining in Boston . . . . . . . . 19

The Federal Reserve Bank Study (20); The Finn Study

(24); The Effects of Redlining (26)

SUMMARY OF BANR LENDING PRACTICES . . . . . . . . . . . 27

CHAPTER FOUR: ALTERNATIVE FINANCING OPPORTUNITIES:

MORTGAGE COMPANIES . . . . . . . . 29

MORTGAGE COMPANY PRACTICES ................ . . 30

The Role of Mortgage Companies Within the Mortgage

Finance System (31)

Mortgage Company Lending Practices in Boston . . . . . . . 35

FEDERAL RESERVE BANK STUDY OF MORTGAGE COMPANY LENDING

PRACTICES . . . . . . . . . . . . . . . 35

Data Sources and Methodology (35); Major Findings of

the Federal Reserve Bank Study (38)

UNAC RESEARCH OF MORTGAGE COMPANY LENDING PRACTICES . . . . . 39

Data Sources and Methodology (39)

ANALYSIS OF MORTGAGE COMPANY LENDING PATTERNS BY THIS

AUTHOR . . . . . . . . . . . . . . . . . . . . . . .

Hethodology and Data Sources (41); Further Analysis of

Mortgage Company Lending Patterns (42); Number of

Loans per Property (44); Interest Rates (45);

Contractor Lending Practices (46); Violations of 
Truth-In-Lending Requirements (47); Household Income Information (48)

SUMMARY OF MORTGAGE COMPANY LENDING PRACTICES . . . . . . . 48

CHAPTER FIVE: EFFORTS TO REMEDY THE

"SECOND MORTGAGE SCAM" . . . . . . . 51

THE CITY RESPONDS TO THE "SCAM" . . . . . . . . . . . . . . 51

CHAPTER SIX: CONCLUSIONS . . . . . . . . . . . . . . . . . . 55

CONCLUSIONS . . . . . . . . . . . . . . . . . . . . . 55

RECOMMNDATIONS . . . . . . . . . . . . . . . . . . . . 57

FUTURE RESEARCH . . . . . . . . . . . . . . . . . . . 60

GLOSSARY ........................ 61

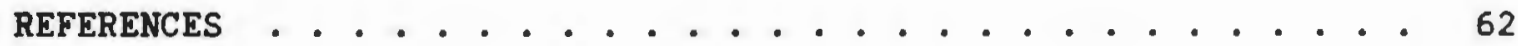


Table 3.1 MORTGAGE LENDING BY BOSTON'S BANRS, 1981-1987 • . . . 20

Table 4.1 TOP TEN INDEPENDENT MORTGAGE COMPANIES, 1988 . . . . . . 33

Table 4.2 LOCAL MORTGAGE COMPANIES AND THEIR BANK AFFILIATES, 1990 . . . . . . . . . . . . . . . . . 34

Table 4.3 SUMMARY OF MORTGAGE COMPANY LOANS BY RATE, 1987-1990 • 38

Table 4.4 SUMMARY OF MORTGAGE LENDERS, ROXBURY/MATTAPAN AND SUFFOLR COUNTY . . . . . . . . . . . . . . . 39

Table 4.5 NUMBER OF MORTGAGES ON PROPERTIES . . . . . . . . . . 44 
CHAPTER ONE

INTRODUCT ION 


\section{CHAPTER ONE: INTRODUCTION}

INTRODUCTION

The "American dream" is synonymous with homeownership. For some, the expression inspires a vision of family life in the suburbs; for others it represents an urban lifestyle. In either case, the ability to purchase and maintain a home remains at the center of the ideal.

A home represents the single largest purchase of most households in the United States. Few households are able to purchase a house without some form of long-term financing. Consequently, homeownership is dependent on the availability of credit.

While regulated banking institutions are the most common resource for home financing, their products are not evenly distributed throughout all neighborhoods. Residents of inner-city neighborhoods, particularly those with a high percentage of minorities, often find that regulated banks (italicized words are defined in the glossary) do not provide financing in their neighborhoods. Other institutions, such as unregulated mortgage companies, may supply the unmet demand for financing opportunities, but often at a higher cost to the borrower.

The higher cost of borrowing from mortgage companies is supposedly justified by the higher risk associated with inner-city housing stock and risk of loaning to low- and moderate-income households (Couture 1992). The constraints imposed on regulated banks, such as disclosure requirements and interest rate caps, are not applicable to unregulated mortgage companies.

Inherent in the unregulated environment is the potential for abuse. While mortgage companies provide a service to homeowners by 
allowing access to the equity in homes, some mortgage companies have packaged loan products that are very burdensome to borrowers, and that often result in foreclosure.

Statement of Purpose

This research project addresses the issue of home financing opportunities in selected neighborhoods of Boston, Massachusetts. The scope of the inquiry is limited to the lending practices by regulated banks and unregulated mortgage companies in Roxbury, Dorchester and Mattapan from 1985 to 1990. The research is in response to a "second mortgage scam" that is alleged to be practiced by mortgage companies in these neighborhoods.

Major Questions

To review these lending practices, four major questions are answered in this report. The questions are:

1) What are the lending patterns of Boston's major banks in Roxbury, Dorchester and Mattapan?

2) What finance structure enables unregulated mortgage companies to operate?

3) Who are the unregulated lenders in violation of established lending standards, and in what neighborhoods do they operate?

4) What efforts are being made at a city and state level to promote industry standards and prevent future foreclosures? Objectives of the Research

To begin the research, Chapter Two, Selected Neighborhood Characteristics, will present a brief demographic profile of Roxbury, Dorchester and Mattapan. The objective of the profile is to describe 
the median income and racial mix of the nelghborhoods most affected by mortgage company lenders. Chapter Three addresses the first major question by assessing lending patterns of Boston's major banks. The objective is to compare the lending patterns in Roxbury, Dorchester and Mattapan with other neighborhoods of similar socio-economic characteristics. Chapter Four answers the second question through a brief explanation of the relationship between regulated banks and unregulated mortgage companies. Chapter Four also answers the third question in that it describes the lending patterns of mortgage companies in Boston's selected neighborhoods, Roxbury, Dorchester and Mattapan. The first objective of Chapter Four is to explain the financial structure that enables mortgage companies to operate. The second and most important objective of this chapter is to analyze the loan products of unregulated mortgage companies, and determine the geographic distribution of these products. Chapter Five addresses the final question of local governmental attempts to seek an equitable solution to the problem of very burdensome loans by mortgage companies. The objective is to provide a sample of the legislation and programs introduced by Boston city officials at the time of this writing to remedy the situation. Chapter Six offers conclusions and recommendations.

\section{Organization}

For each chapter of this research project, the objective is restated, and the data sources are presented, followed by the methodology used to analyze the data. The major findings will conclude each chapter. 


\section{Me thodology}

The methods used in this research project include a review of published research on redlining in Boston, Massachusetts, by the Federal Reserve Bank of Boston (Bradbury 1989) and the Boston Redevelopment Authority (Finn 1989). Mortgage company lending patterns were determined by a review of an unpublished research document by the Federal Reserve Bank of Boston (Munnell and Browne 1991), and other unpublished data. Identification of legislation and program initiatives directed at preventing future home foreclosures was made by a review of newspaper articles on the topic. The author recognized that news items constitute secondary data and are sometimes prone to editing and typographical errors. Therefore, further information on laws and programs was compiled and verified through telephone interviews with key informants.

Data Sources

Data used in this research project include published and unpublished material. Chapter Two, Selected Neighborhood Characteristics, is based on statistics from the U.S. Census. Chapter Three, Lending Practices of Boston's Major Banks, is based on data published by the Federal Reserve Bank of Boston (Bradbury 1989), and the Boston Redevelopment Authority (Finn 1989). These two published studies were based on Community Reinvestment Act and Home Mortgage Disclosure Act reports required of regulated banks. Chapter Four, Alternative Financing Opportunities: Mortgage Companies, is based on published and unpublished materials. Published material include essays on mortgage markets by Fannie Mae. Unpublished data include those gathered by the 
Federal Reserve Bank of Boston and the Union Neighborhood Assistance Corp. on unregulated lenders from the Suffolk County Registry of Deeds records.

\section{BACRGROUND}

The so-called "second mortgage scam" occurred during the latter part of the 1980 s in the neighborhoods of Roxbury, Dorchester and Mattapan. The lending practices of a few mortgage companies, sometimes working with contractors, have come under extreme criticism by community groups, legislators and community officials for their lending practices. These mortgage companies include, as this study will show, the Resource Companies loperating under several names, such as Resource Funding, Inc., Resource Lending, Inc., Resource Financial Group, Inc., Resource Services, Inc., and Resource Mortgage Corp), Growth Mortgage Corp., and Chrysler First Credit Corp. The contractors include U.S. Window Corp., and Vinyl Distributors of New England Inc., and others. The criticisms have included failing to research the borrower's ability to repay the debt, charging usurious interest rates, for fraud, and for violations of truth-in-lending laws. Many homeowners in Boston have lost their homes as a consequence of doing business with these companies. These mortgage companies are called "hardlenders" by the media and many community groups to differentiate them from other unregulated mortgage companies.

The Boston media, including television and newspapers, offered considerable coverage of the situation during the summer of 1991 as victimized homeowners began to make their stories public. Neighborhood community organizations and city officials began to research the lending practices of these companies, and to hold public meetings to educate 
low- and moderate-income families about the high risk associated with doing business with them. These activities encouraged more victimized homeowners to come forward, making it possible to learn of the lending patterns used by these companies and to determine the extent of their lending activities.

While the initial research was made available to the public by community groups, city officials began to conduct educational meetings to inform residents of Roxbury, Dorchester and Mattapan of the names and practices of the hardlenders. One such meeting, sponsored by the Mattapan Civic Improvement Association, was held at the local police station on June 24, 1991. Diane Watson, Commissioner of Elderly Affairs, and Diane Modica, Commissioner of Consumer Affairs and Licensing, City of Boston, took the opportunity to expose the pattern used by the loan originators to obtain the borrower's signature (Modica 1991).

Modica reported a pattern that typically begins with a contractor arriving at the home, pointing out the need for repairs. This is often a persuasion based on fears: weak steps might cause an elderly individual to fall and break a hip, creating extensive medical bills. The contractors usually attempt to gain the trust of the homeowner by completing a small repair (under $\$ 500$ ) of quality construction and on schedule.

Once trust has been established, the contractor typically returns with a more extensive list of repairs, and many documents for the homeowner to sign. Included in the document package are: 1) completion certificates, which the homeowner signs, in advance, to authorize that 
the work has been completed satisfactorily, and 2) loan agreements, often in violation of truth-in-lending laws. Modica reported that high pressure sales tactics are commonly used, such as the offer of discounted prices if the agreement is signed immediately.

Many victims reported that papers, attached to a clipboard, covered what they later discovered were the interest rate and loan agreement section of the document. Additionally, it was reported that the three day right to rescind section of the contract, required by truth-in-lending laws, was missing or obscured. After a contract was signed, the contractor seldom completed the work to a satisfactory level. The borrower, of course, was still obligated to pay the loan. In a law suit filed by the Massachusetts Attorney General against the Resource Companies, the victimized homeowners testified that loan originators falsified the contracts. Borrowers were told they were receiving a long-term (15 year) agreement, with interest rates between 15- and 18-percent annually. In fact, the agreements were high interest (20-percent or more), short-term (two years), interest-only loans, with balloon payments due at the end of the term. The court record states that loan originators often promised the borrowers that these agreements were only temporary and necessary to begin the home improvements, and that more traditional financing would be avallable before balloon payments were due. Traditional financing was not made available at a later date, and many homeowners found themselves in foreclosure procedures (Commonwealth of MA v. Resource Financial Group, Inc., Resource Lending, Inc., Resource Services, Inc.) 
The Worst Consequence, Foreclosure

By law, foreclosure notices must be printed in local newspapers. Foreclosure notices are a source of information for other mortgage company loan originators. Unregulated Boston-based loan originators commonly used such information to solicit the affected homeowners with the promise of saving their homes with more financing. Typically, those subsequent loans were also short-term, balloon debts which allowed the homeowner to pay off the original debt and prevent immediate foreclosure, but at an increasing amount of debt. Eventually, many properties were sold to pay the debt. Second or third mortgage companies often foreclosed on properties (Marks 1992).

\section{SUMMARY}

Such practices have a destabilizing effect on both the affected households and their neighborhoods. Homeowners lose the equity built in their homes, which can cause financial difficulties. The homeowner is also forced to leave after the foreclosure. To maximize the income from rental properties, maintenance is reduced resulting in deterioration that can spread throughout the neighborhood, further destabilizing the community (Achtenberg and Marcuse 1986). Most of the housing units in Roxbury, Dorchester and Mattapan are multi-family dwellings. Review of the Suffolk County Registry of Deeds records indicate that many of the foreclosed homes were purchased by absentee landlords. 
CHAPTER TWO

SELECTED NEIGHBORHOOD CHARACTERISTICS 


\section{NEIGHBORHOOD CHARACTERISTICS}

The objective of this chapter is to describe the income and minority population of Roxbury, Dorchester and Mattapan. This information is useful in determining which households are likely to be granted or denied credit. Selected neighborhoods in Boston are discussed, including the area name, planning district, median household income levels for 1980 and 1987, and the percent of black population. Data Sources

Sources of statistical information on neighborhood characteristics include census data and statistics compiled by the Boston Redevelopment Authority (BRA). Geographic units of analysis include planning districts, defined by the BRA; census tracts; and neighborhood statistical areas (NSAs). NSAs are used in this discussion. Planning districts are used only to identify the respective communities. Neighborhoods, Median Incomes, and Populations

The following list includes information regarding the neighborhoods most affected by the hardlenders: 


\begin{tabular}{|c|c|c|c|c|}
\hline $\begin{array}{l}\text { Jeighborbood/ } \\
\text { Plenning District }\end{array}$ & $\begin{array}{c}1980 \\
\text { Iedian } \\
\text { Housebold } \\
\text { Incone }\end{array}$ & $\begin{array}{c}1987 \\
\text { Yedian } \\
\text { Housebold } \\
\text { Incone }\end{array}$ & $\begin{array}{c}1980 \\
\text { Percent } \\
\text { Population } \\
\text { Black }\end{array}$ & $\begin{array}{c}1980 \\
\text { Population }\end{array}$ \\
\hline $\begin{array}{l}\text { Dudley, Brunswick liag/ } \\
\text { Roxbury }\end{array}$ & $\$ 9.669$ & $\$ 16.649$ & 671 & 12.033 \\
\hline $\begin{array}{l}\text { Ashoont/So. Dorchester } \\
\text { Bowdoin B., Wt. Bowdoin/ }\end{array}$ & 17,137 & 28,621 & 6.5 & 6,883 \\
\hline $\begin{array}{c}\text { So. Dorchester } \\
\text { Codman Sq., I We Can, I. }\end{array}$ & 8,868 & 15,858 & 63.0 & 4,921 \\
\hline $\begin{array}{l}\text { Codian Bl/So. Dor. } \\
\text { E. Lower Mills, Cedar Grove/ }\end{array}$ & 11,360 & 19,420 & 77.0 & 9,884 \\
\hline So. Dorchester & 14,303 & 34,211 & .7 & 5,679 \\
\hline Fields Corner East/So.Dor. & 11,238 & 24,394 & 1.4 & 2,111 \\
\hline Fields Corner Hest/So.Dor. & 14,336 & 24,730 & 52.5 & 5,881 \\
\hline $\begin{array}{l}\text { Ieeting House Hill/So.Dor. } \\
\text { Ieponset, Port Iorfolk/ }\end{array}$ & 11,795 & 24,037 & 20.8 & 6,803 \\
\hline So. Dorchester & 16,368 & 32,727 & .7 & 8,317 \\
\hline $\begin{array}{c}\text { St. Marks/So. Dorchester } \\
\text { W. We Can, U.Codnan Ml., } \\
\text { H.Lower Mills/ }\end{array}$ & 14,429 & 31,668 & 8.1 & 8,644 \\
\hline $\begin{array}{c}\text { Mattapan } \\
\text { Pranklin Pield Jorth }\end{array}$ & 14,621 & 31,936 & 59.4 & 5,951 \\
\hline $\begin{array}{c}\text { Porbury } \\
\text { Franklin Field Soutb/ }\end{array}$ & 10,112 & 17,048 & 94.4 & 6,859 \\
\hline Kattapan & 9,608 & 15,290 & 90.5 & 10,362 \\
\hline Esgleston Sq./Roxbury & 9,690 & 18,200 & 31.0 & 6,505 \\
\hline Soutbern Mattapan/Mattapan & 16,183 & 22,073 & 76.1 & 12,008 \\
\hline Wellington Bill/Kattapan & 12,849 & 23,932 & 91.8 & 7,506 \\
\hline Higbland Park/Roxbury & 8,965 & 17,623 & 76.0 & 3,252 \\
\hline Lower Roxbury/Roxbury & 6,401 & 45,352 & 84.7 & 4,494 \\
\hline Savin-Moreland/Rorbury & 10,625 & 19,187 & 85.0 & 6,099 \\
\hline Washington Park/Roxbury & 9,582 & 20,087 & 91.1 & 18,550 \\
\hline
\end{tabular}

The median household income throughout the city of Boston in 1987 was $\$ 32,980$ (Apgar 1991). The statistics indicate that many of the households of Roxbury, Dorchester and Mattapan are below the median household income for the city. Most would not qualify for mortgages under traditional lending guidelines.

The statistics suggest, however, that median incomes in a few neighborhoods might be sufficient to qualify for mortgages or home improvement loans under the traditional standard. Of course, loan approval should be based on individual income and total household debt. 
Still, it appears that some households would qualify for traditional lending opportunities.

SUMMARY OF NEIGHBORHOOD CHARACTERISTICS

The objective of this chapter was to present selected neighborhood characteristics of Roxbury, Dorchester and Mattapan, including median household income levels and the percentage of minorities. The data suggest that many households would have difficulty in carrying debt, as incomes are below the median income level. There are several neighborhoods, however, with residents earning enough income that some would probably qualify for traditional financing opportunities. 
CHAPTER THREE

LENDING PRACTICES OF BOSTON'S MAJOR BANRS 


\section{BANRING PRACTICES: REDLINING IN BOSTON}

\section{INTRODUCTION}

Deregulation of the banking industry has bad broad effects across the housing market, particularly in New England. Speculative investments in condominiums, commercial real estate, and much of the single family housing stock in urban areas has weakened the solvency of many financial institutions, resulting in less mortgage credit availability throughout the industry. The credit crunch that affects the housing market for many low-income, minority New Englanders today, however, is the continuation of a long-standing trend of disinvestment In certain socio-economic neighborhoods.

This chapter examines the practice of redlining in Boston, and addresses the first major question of the research: what are the lending practices of Boston's major banks? The first section, Redlining, defines redlining, and the predictable stages of neighborhood transition. The second section, Evidence of Redlining in Boston, reviews some of the fundamental causes of bank lending restrictions in inner-city neighborhoods (the Federal Reserve Bank of Boston Study). This is followed by a review of the effects of redlining on lower socioeconomic neighborhoods of Boston (the Finn Study).

Section One, Redlining

The Prevalence of Redlining Over Time

Redlining is defined as the failure of financial institutions to provide loans in certain neighborhoods for buying and fixing houses (Stone 1986). While federal legislation, such as the 1977 Community 
Reinvestment Act, has attempted to discourage this practice, it continues as it has for some time.

During the 1950s, FHA and VA guidelines served to constrict the consideration of applications for mortgage financing from integrated or minority areas. This practice had the effect of redlining large areas of urban development (Citizens Commission of Civil Rights 1986). While these institutions have changed their policies, similar effects result from other practices throughout the industry. The Federal National Mortgage Association (FMMA), the Government National Mortgage Association (GMMA), and the Federal Home Loan Mortgage Corporation (Freddie Mac) have established strict underwriting standards based on suburban single family development, which continues to leave inner-city neighborhoods at a mortgage credit disadvantage (Ferguson 1991).

In 1971, the National Urban League conducted a study of housing decay and abandonment in seven major cities throughout the United States. The study concludes that redining was prevalent in urban areas throughout the country at that time (Listokin 1980).

More recently, two studies have been conducted in Boston to assess lending opportunities in minority nelghborhoods. Both studies have determined that redlining, despite the housing boom of the 1980s, is still a common occurrence (Bradbury 1989) (Finn 1989).

\section{The Transition of Neighborhoods}

Neoclassical economic theory suggests that housing filters down. Consumer choice is the motivating factor behind the deterioration of neighborhoods. The theory sees the change as a series of inevitable, "natural" events. It assumes that individual choices to move trigger 
decline and abandonment, and that banks react to, rather than encourage the neighborhood change process. Investors purchase housing after families move out, and reduce maintenance on the building to enhance profits. The next phase in the process is redlining by financial Institutions (Meyerson 1986a).

This theory is founded on demand-side, rather than supply-side economics. It fails to acknowledge the role of banking policies, particularly in inner-city neighborhoods, that influence household preferences (Meyerson 1986a).

The Urban League research revealed a predictable pattern of stages in the deterioration of urban neighborhoods. The first evidence of change in a neighborhood, according to the study, is a difference in socio-economic status. The second stage is a change in the racial character of the neighborhood, with whites leaving and blacks entering. The third stage shows evidence of property speculation and exploitation, followed by deterioration of market conditions and disinvestment by both the financial institutions and the property owners who stop maintaining the property. The final stage in the process is abandonment (Listokin 1980).

Fundamental Causes of Housing Deterloration

The primary cause of housing problems in the United States is that housing is motivated by profit. Inner-city absentee landlords invest the least amount of maintenance costs to maximize profits on the investment. This practice ensures that housing conditions will deteriorate. Homeowners within the same neighborhood are affected by the practice as well. Mortgage lending institutions are likely to 
consider these neighborhoods "high-risk" and restrict credit to the area. Although poverty is a factor that must be analyzed in lending practices, the area-wide credit restrictions serve to prohibit access to mortgage funds for those households with the ability to repay their debts (Achtenberg and Marcuse 1986).

That housing is not considered a right is reflected in the lack of a comprehensive federal policy to ensure a safe shelter. Federal policies and programs have been compromised to special interests, resulting in a series of schemes that, for lack of permanent investment, have been almost guaranteed to fail (Achtenberg and Marcuse 1986).

Deregulation of the banking industry has the effect of consolidating banking activities into huge, multinational financial institutions. Big bank mergers result in the need to cut expenses, often achieved by closing down branches. This practice causes inconvenience to individuals in the affected neighborhoods and can reduce avallable funds for mortgage lending (Meyerson 1986b).

Additionally, decisions to offer construction and mortgage loans are often made on real or perceived expectations of risk. Accordingly, banks create a self-fulfilling prophecy when they restrict credit in a particular neighborhood. Even during periods of economic activity, these areas deteriorate (Finn 1989).

Boston's inner-city neighborhoods, particularly Roxbury, Dorchester and Mattapan, have felt the effects of redlining. This is due, in part, to the economic boom of the 1980s. Some areas of the city were selected for redevelopment and gentrification, such as the South End, Bay Village and Chinatown. Many households that were dislocated in 
this process have woved to Dorchester and Roxbury because the rent costs were relatively less expensive. An increase in the Asian population in Roxbury from 1.9 percent in 1980 to 3.8 percent 1990 is evidence of this change (U.S.Census of the Population, 1980 and 1990).

Gentrification was actively promoted by the actions of city government. It channelled federal funds into upscale areas, offered tax breaks and/or public land to developers, and restricted the activities of community development corporations to less desirable areas (McAfee 1986). Although gentrification did not occur in all nelghborhoods, it had the effect of increasing housing costs, including rent, throughout the city. One effect of gentrification was the increase in condominium conversions. Over 20,000 rental units throughout the city were converted, reducing the supply of rental units and increasing the cost of the remaining rental units. By 1988, Boston had become the fourth least affordable housing market in the country (Finn 1989).

The recent downturn of the economy forced the city to cut back on many soclal services, including schools, health centers, and bus routes (McAfee 1986). Economic forces have an effect on private enterprise as well, particularly in the banking industry. The effects of the recession of the early 1990 s is most evident in the minority neighborhoods of the city.

\section{Section Two, Evidence of Redlining in Boston}

An underlying assumption in this research is that if traditional mortgage and home improvement funds are available to minorities, the need to seek alternative financing is unnecessary. Therefore, an investigation of traditional sources of financing is appropriate. 
The Federal Reserve Bank and The Boston Redevelopment Authority Studies

A thorough examination of traditional lending opportunities offered by banks throughout the city of Boston was completed in two studies released in 1989. The first was produced by the Federal Reserve Bank of Boston, and written by Ratharine Bradbury and others. The second was conducted by Charles Finn and commissioned by the Boston Redevelopment Authority.

Both studies utilized Community Reinvestment Act (CRA) reports. Neighborhood statistical areas (NSAs) defined by the Census Bureau and the Boston Redevelopment Authority were used to examine banking activities at a neighborhood level. Both studies used Home Mortgage Disclosure Act (HMDA) reports as a source of primary data, in addition to data on mortgages maintained by the Suffolk County Registry of Deeds and published by Banker \& Tradesman, a weekly publication offering specific information on real estate and banking matters. In addition, the Finn study used Massachusetts Housing Finance Agency (MHFA) data on loans applied to the area NSAs (Bradbury 1989) (Finn 1989).

Bank lending practices in the city are summarized in Table 3.1 (page 20). Banks are ranked according to levels of banking activity from the largest banks (with more than one billion dollars in deposits), to the smaller banks (those with deposits of less than one billion dollars.) Clearly, the majority of banks in the city are not investing in the minority neighborhoods, as indicated by the white/minority lending ratios.

Some of the institutions listed in the table have gone out of business since 1989. These include First American Bank and Eliot 


\begin{tabular}{|c|c|c|c|}
\hline Int & $\begin{array}{l}\text { Mite/linority } \\
\text { leighorlood } \\
\text { latio } \\
\end{array}$ & $\begin{array}{c}\text { latio lrcloding } \\
\text { Gor't Gurmteel } \\
\text { Loms } \\
\end{array}$ & $\begin{array}{l}\text { Potal kposits } \\
\text { (I-tillious, } \\
\text { U-nillions) }\end{array}$ \\
\hline Pirst Jat'l Bank of Boston & $2.1: 1$ & $2.1: 1$ & $\$ 7.4828$ \\
\hline Bank of Ilew England & $1.9: 1$ & $2.6: 1$ & $\$ 6.029 B$ \\
\hline State Street Bank & 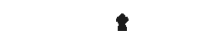 & 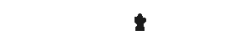 & $\$ 3.983 B$ \\
\hline Shawnut Bank & $2.3: 1$ & $12.0: 1$ & $\$ 3.131 \mathrm{~B}$ \\
\hline Boston Pive & $0.9: 1$ & $0.9: 1$ & $\$ 1.466 \mathrm{~B}$ \\
\hline The Provident & $4.2: 1$ & $8.0: 1$ & $\$ 1.146 B$ \\
\hline Honeowners & yLm & ILII & $\$ 1.1068$ \\
\hline U.S. Irust Conpany & $1.6: 1$ & $1.8: 1$ & $\$ 888.891 X$ \\
\hline Soutb Boston Savings & $7.4: 1$ & $7.6: 1$ & $\$ 766.185 \|$ \\
\hline JeVorld Bank for Savings & $1.9: 1$ & $2.0: 1$ & $\$ 764.816 \%$ \\
\hline First Mutual of Boston & $2.5: 1$ & $2.4: 1$ & $\$ 563.696 \%$ \\
\hline $\begin{array}{l}\text { Baybank of Boston, } \\
\text { garvard Irust and }\end{array}$ & & & \\
\hline Iorfoll & $11.7: 1$ & $11.7: 1$ & $\$ 433.230 \mathrm{~K}$ \\
\hline First American Bank & $0.6: 1$ & $0.7: 1$ & $\$ 355.451 \mathrm{X}$ \\
\hline Capitol Bank and Irust & $10.2: 1$ & $10.2: 1$ & $\$ 328.7181$ \\
\hline Baymarket Cooperative & ILIII & ILm & $\$ 325.6068$ \\
\hline Boston Irade Bank & 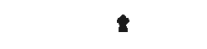 & $\bullet$ & $\$ 246.611 \mathrm{H}$ \\
\hline Eliot Savings Bank & $1.5: 1$ & $2.0: 1$ & $\$ 228.320 \mathrm{H}$ \\
\hline East Boston Savings Bank & $43.3: 1$ & $42.8: 1$ & $\$ 217.651 \%$ \\
\hline Olympic International & + & 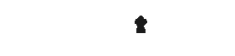 & $\$ 179.480 \mathrm{H}$ \\
\hline Workingren's Cooperative & $3.6: 1$ & $3.5: 1$ & $\$ 176.211 \mathrm{H}$ \\
\hline Overall ratio (all banks) & $2.9: 1$ & $3.4: 1$ & \\
\hline \multicolumn{4}{|c|}{ 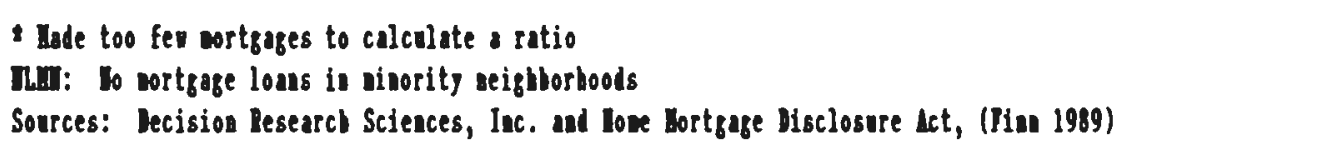 } \\
\hline
\end{tabular}

Savings Bank. The Bank of New England has since been purchased by the Fleet/Norstar Group.

The Federal Reserve Bank Study

The authors of the Federal Reserve Bank study assert that Roxbury, Mattapan and parts of Dorchester are not receiving a fair share of financing opportunities. Various non-racial factors are included in the analysis, including adjustments for less wealth, lower incomes, lowervalued housing, and less housing development. Such adjustments reduce the size of the discrepancy in lending by race, but there remains a 24 
percent difference in lending practices between neighborhoods with predominately white populations and predominately black populations (Bradbury 1989:4).

The authors of the Federal Reserve Bank study investigated the financial sources for real estate transactions by type of lender between 1982 and 1987. The sources of data included the file of individual deed transfers maintained by the Suffolk County Registry of Deeds. Because this file contained commercial and industrial transactions as well as residential sales, an adjustment was completed to more accurately reflect residential sales activities throughout the city. The findings of the city-wide analysis indicate that nearly 60 percent of all transactions in Boston during this period were financed by banks, thrifts and their affiliated unregulated mortgage companies. An additional 15 percent were financed by unregulated mortgage companies not affiliated with commercial banks or thrifts. Other private lenders, including credit unions, sellers, real estate trusts, pension funds and others, accounted for 6.5 percent. 19 percent of the transactions were shown to have no mortgage financing (Bradbury 1989:5-10).

Further analysis of real estate transactions and mortgages were completed for the years 1982 through 1987 to examine the racial integration of the neighborhoods. Neighborhoods were categorized on the basis of racial composition, ranging from those with nearly all white populations to neighborhoods whose populations were largely black. The neighborhood boundaries are those defined by NSA criteria, and included populations which were composed of, roughly:

a) less than 5 percent black residents, 
b) between 5 and 20 percent black residents,

c) between 20 and 50 percent black residents,

d) 50 and 80 percent black residents,

e) more than 80 percent black residents.

For purposes of the Federal Reserve Bank study, Asians and other minority groups were included as white.

The results of the analysis indicate a very different pattern of lending in neighborhoods with a majority white population as compared to neighborhoods with a majority black population. In neighborhoods with a majority white population, about 8.6 percent annually of all properties were sold between 1982 and 1987, with an annual average of 6.9 percent of the properties accepted for traditional mortgage financing. In the neighborhoods with a majority black population, 5.2 percent of the properties sold, with 3.5 percent receiving bank financing (Bradbury $1989: 12-13)$.

In neighborhoods less integrated, the differences are even greater. Bradbury reports:

"In neighborhoods with populations that were less than 5 percent black, mortgages were originated on an average of 6.8 percent of structures in an average year. In neighborhoods with populations that were more than 80 percent black, mortgages were originated on only 2.7 percent of structures in an average year" (Bradbury $1989: 13)$.

The number of transactions is dependent on both the supply of and demand for housing. New construction and the number of condominium conversions affect the supply, and periods of increased activity, such as the $1980 \mathrm{~s}$, can create increased mortgage lending activity in one area over another. Housing demand is affected by household earnings, age, 
family size and composition, and other factors. The study controlled for these variables, as well as the fact that the majority of the population in Boston was white and that whites might have been reluctant to move into black areas. This served to reduce the pool of potential buyers in black areas. It was determined that white householders were more mobile than their black counterparts, and that blacks had less opportunities for the sale or purchase of homes (Bradbury 1989:16). Other variables used in the study to explain the difference in lending, by race, include the percent of black residents, the percent of other minorities, income, wealth, median value of single-family owneroccupied housing, rent, vacancy rate, commercial and industrial property, mobility, age, housing development, depository institution offices and economic conditions over time. Raw data utilized before the regression analysis indicates that there was a 60 percent difference in the number of transactions in neighborhoods with black and white populations. This figure is adjusted to allow for the variables. Nonetheless, neighborhoods w1th largely black populations receive 24 percent fewer mortgage transactions than neighborhoods composed of mostly white residents after adjustment (Bradbury 1986:18-21).

Transactions with no recorded mortgages were also examined. This type of housing transaction accounts for approximately one-fifth of the sales between 1982 and 1987 . There is a noticeable variation of percentages of transactions with no recorded mortgages across the neighborhoods. While these transactions accounted for less than 20 percent of the total sales in neighborhoods with a majority of white 
residents, over 40 percent of the structures sold in neighborhoods with more than 50 percent black residents were unfinanced (Bradbury 1989:21). According to the Bradbury study, it is clear that banks and thrifts are not lending unilaterally throughout Boston's neighborhoods. Race has been determined to be a principal factor in determining the desirability of lending in the area.

The Finn Study

The Finn study was published subsequent to the Federal Reserve Bank report. Finn used a different approach in his research. Rather than stressing neighborhood characteristics as causes of lending trends, Finn interpreted these variables as influenced by lending practices. The focus of this section, then, is on the demand for mortgage financing as an explanation for bank lending practices (Finn 1989:4).

Finn concluded that the economic boom of the 1980 s has put the rate of homeownership for blacks well below the rate for whites. In fact, homeownership opportunities for blacks in Boston ranked last of 48 metropolitan areas in 1980. The rate of homeownership for black Bostonians was 41.3 percent, while the average of the 48 metropolitan areas was 66.5 percent (Finn 1989:7). Additionally, the ratio of mortgage loans per 1,000 units was 2.9 in neighborhoods with a majority white population to 1 in neighborhoods with a majority black population between 1981 and 1987 (Finn 1989:1i).

The Community Reinvestment Act requires banks to provide mortgage funds to all neighborhoods, while maintalning sound banking practices. The ability to repay debt is, of course, dependent on incowe. 
Therefore, it might be assumed that variations in lending practices would be based on income. However, this is not the case.

Finn categorized neighborhoods and census tracts into groups of Income "deciles", a category which reflects income based on 10 percent of the census tract or neighborhoods. Three income categories were utilized :

"(1) the first through third deciles (median family incomes below $\$ 28,805$ in 1987); (2) the fourth through sixth deciles (median family incomes between $\$ 28,805$ and $\$ 46,455$; and (3) the seventh through tenth deciles (median family incomes above $\$ 46,455$ )" (Finn $1989: 15$ ).

Application of these categories to mortgage loans made per 1,000 units revealed that the lowest income category received 67 loans, while the middle income category received 53 loans, and the highest income category received 85 loans per 1,000 units (Finn 1989:15).

Finn determined a significant difference, however, in the levels of financing between neighborhoods of the same income but with different racial characteristics. The Dudley, Brunswick Ring section of Roxbury, for example, a neighborhood with a 67.1 percent black population, received 17 loans per 1,000 units, while the West Fens neighborhood, an area with an 8.4 percent black population, received 192 loans per 1,000 units (Finn 1989:15). In the planning districts (a larger unit of measure than neighborhoods) of Roxbury and Mattapan, only 33 and 35 mortgage loans per 1,000 units were found. Similar planning districts with a majority white population showed a range of loans, from 47 to 148 (Finn 1989:21).

The Finn study includes analysis of home improvement lending not analyzed by the Federal Reserve Bank research. The pattern Finn 
described for home improvement lending is opposite that of mortgage lending, "banks actually provided more home improvement loans per 1,000 units in Boston's minority census tracts than they did in white census tracts with comparable incomes" (Finn 1989:27). The ratio of home improvement loans to black residents, by census tract, was $.55: 1$, a trend that held in all income deciles. This may be interpreted as acknowledgement by banks of creditworthy individuals living in minority neighborhoods. The type of loan, of course, is different. Home improvement loans are typically higher-interest, shorter-term debts than mortgage loans. The increased activity may reflect the increasing value of these homes, and the suitability of the structures for future sale and mortgage financing (Finn 1989:27-29).

The Effects of Redlining

While there are many personal stories of hardship as a result of rediining, the effects spread throughout the entire community. Neighborhoods begin to deteriorate without a steady flow of funds, and during periods of economic growth, disinvested neighborhoods suffer in even greater proportions (Finn 1989).

Regulated lenders have put considerable investments into condominiums, especially in lower-income neighborhoods with largely majority white populations. The effect of this practice is to reduce the supply of affordable rental units. This, in turn, can affect the economic development of the area. Many of the job opportunities expected to increase in the near future are service-oriented jobs. Traditionally, this type of employment pays less than manufacturing 
jobs. High rent costs can reduce the available labor pool, and stifle economic growth over the long run (Finn 1989). SUMRARY

The objective of this chapter was to answer the question, what are the lending practices of Boston's major banks? Studies completed by the Federal Reserve Bank of Boston and Charles Finn provide evidence that redlining, especially for home mortgages, has occurred in minority neighborhoods throughout the city. Even with income adjustments, the city-wide ratio of lending in white and black borrowers is $2.9: 1$. In other words, white borrowers are nearly three times as likely to receive loans than are black borrowers. Some neighborhoods have experienced a ratio higher than the city average.

Although home mortgages are not readily available in minority areas, home improvement loans by banks show the reverse trend. The high level of activity in minority neighborhoods by unregulated mortgage companies for home improvements may be a result of real or perceived discrimination by banks.

It is evident that Boston's banks are not meeting their Community Reinvestment Act (CRA) requirements. The CRA requires that regulated banks develop products that meet the needs of the community they serve, including low- and moderate-income areas. Banks have a positive obligation to market and advertise "programs for lending products and services that are responsive to the needs of the community and that will inform and stimulate awareness of those products and services throughout the community, including low- and moderate-income areas" (Federal Reserve Board, Comptroller of the Currency, et al, 1989:6). Such a 
statement can be interpreted as awareness of the impact of a negative perception.

The following section of this report, Chapter Four, will examine the lending practices of mortgage companies throughout the city. For minority neighborhoods, this resource appears to be a major opportunity for financing not afforded by banks. 


\section{CHAPTER FOUR}

\section{ALTERNATIVE FINANCING OPPORTUNIIIES:}

MORTGAGE COMPANIES 
MORTGAGE COMPANY PRACTICES IN BOSTON

The preceding chapter reviewed redlining in Boston and the extent of mortgage lending by regulated banks in nelghborhoods with a majority white population and those with minority populations. It is clear that Roxbury, Dorchester and Mattapan have been redlined. Even though banks offer home improvement loans at a higher ratio to black nelghborhood residents over white neighborhood residents, it is likely that black residents perceive that they have little or no access to traditional sources of financing.

The failure of Boston's banks to make loans in minority neighborhoods creates a demand for financing that is being met by nontraditional institutions, including mortgage companies. Mortgage companies are defined in this context as those lending compantes which are not regulated by the Federal Reserve Board, Comptroller of the Currency, and other government regulatory agencies. The mortgage companies that are analyzed in this project are those that provide loans to borrowers through a line of credit established by the mortgage companies from regulated banks.

This chapter describes the lending patterns of mortgage companies operating in the city of Boston. The second and third major questions presented for analysis are addressed: What finance structure enables unregulated mortgage companies to operate? and, Who are the unregulated lenders in violation of established lending standards and in what neighborhoods do they operate?

Mortgage companies, until recently, operated in an unregulated environment in Massachusetts. Although they offer loans in a manner 
similar to banks, albeit at generally higher interest rates, they do not collect deposits to replenish their funds as banks do. A discussion of the relationship of mortgage companies with banks to replenish mortgage funds will be offered. This discussion is followed by the analysis of mortgage company lending patterns in Roxbury, Dorchester and Mattapan. The Role of Mortgage Companies Within the Mortgage Finance System Deregulation of the banking industry has served to promote fundamental changes with regard to mortgage financing. The supply of mortgage funds is no longer strictly within the domain of savings and loans, as had been the case under the constraints of New Deal legislation before banking deregulation (Florida 1986) (Olson 1990). Other types of regulated banks, such as commercial banks, national banks, or state chartered banks, have attempted to increase their share of mortgage loans. One method of increasing the share of mortgage financing is through mortgage banking firms (Olson 1990).

Mortgage companies often operate in an unregulated market unrestricted by federal or state mandates such as CRA or Howe Mortgage Disclosure Act (HMDA) guidelines. Nor do government safeguards apply to mortgage companies, such as the QTL requirement (Regulation Q) that 70 percent of savings and loans assets be invested in residential mortgages (Olson 1990).

Nortgage companies put their energies into marketing their products. Because they are non-depository institutions, all the loans they originate must be sold either to a bank or, if the mortgage companies are large enough, directly into the secondary mortgage market. Very few mortgage companies, however, are large enough to remain 
Independent of banks. Most operate under a line of credit extended by banks (Rose and Hanley 1990).

This relationship works well for major banks. One result of deregulation has been the consolidation of banks, with the larger Institutions purchasing their smaller competitors. Such purchases, of course, draw on the larger banks' resources, so to strengthen their reserves, the banks will attempt to reduce their costs of doing business. One successful method is to have mortgage brokers originate and service loans. Banks purchase the loans from the mortgage compantes and, in turn, sell those mortgages that meet the criteria of the secondary mortgage market (Olson 1990).

This method eliminates the need for banks to hire personnel to originate and service loans, and also relieves them of constraints imposed be federal or state mandates, such as upper limits on interest charges, or regulatory disclosure requirements. The practice also relieves the banks of any responsibility for loans that might be questionable in terms of interest rates or closing costs and insulates them from public criticism when irregular lending practices are exposed (Canellos 1991).

Of the top 300 mortgage companies in the United States, most are owned by banks. In fact, of the top 100 mortgage companies, only nine are Independent (American Banker 1989). The top ten independent mortgage companies are listed in Table 4.1 (page 34). The ranking is determined by servicing portfolios as of 1988.

The mortgage company that ranked number one, Lomas and Nettleton, incidently, has filed for bankruptcy (Olson 1990). This might suggest 
that the long-term success of mortgage companies will

Table 4.1 TOP TEN INDEPENDENT MORTGAGE COMPANIES, 1988

be determined by their

relationship with the

banking industry (Olson

1990).

Wholesale mortgage

bank activity has been

increasing in recent years.

The opportunity to assume

the role held by savings and

loan institutions before

Pank Asong All

Pirn Mortgage Coppanies

1. Lonas Pinancial Corp.

2. Inco Realty Service 4

3. Waterfield Yortgage

4. Dornan \& Milson

5. Mational Mortgage Co.

6. Tork Associates

7. Cononvealtb Mortgage

8. Colonial Vortgage

9. Guild Mortgage

10. Loan Aserican

Source: Lerican lanter (1989), fron D.A. Olson's article is Journal of Lowiag Research (1990)

banking regulation has proven to be profitable. In periods of decline, the wholesale banks can simply reduce the number of mortgage purchases from brokers rather than reduce personnel or close branch offices. The top 58 largest wholesale mortgage banks volume purchases nationally rose from $\$ 28.5$ billion in 1988 to $\$ 50.9$ billion in 1989 , and was expected to reach $\$ 60$ billion in 1990 (Olson 1990 ).

Banks that have extended lines of credit to mortgage companies operating in Boston are listed in Table 4.2 (page 35). Of the affiliated banks listed in the local list, Fleet Mortgage/Real Estate Funding was ranked number one in the nation's top ten wholesale mortgage banks in 1990, with planned purchases of $\$ 7,300,000,000$ (Olson 1990).

This evidence suggests that recent activity in mortgage lending is for larger banks to establish wholesale mortgage banks to do business with mortgage brokers (Olson 1990). 
Table 4.2 LOCAL MORTGAGE COMPANIES AND THEIR BANR AFFILIATES, 1990

\begin{tabular}{|c|c|}
\hline Mortgage Cospanies & Bank Affiliates \\
\hline $\begin{array}{l}\text { Chrysler First } \\
\text { First Comonwealth Financial } \\
\text { Leader Hortgage } \\
\text { Voney Store }\end{array}$ & $\begin{array}{l}\text { Citicorp } \\
\text { Rockland Irust Co. } \\
\text { Bank Tive for Savings } \\
\text { lew Jersey Bank IA } \\
\text { Dorizon Bank IA } \\
\text { Anerican Jat'l Bank }\end{array}$ \\
\hline $\begin{array}{l}\text { Iew England Financial } \\
\text { Consultants }\end{array}$ & $\begin{array}{l}\text { Saugus Bank \& Trust Co. } \\
\text { Lynn Five \& Colonial Bank } \\
\text { First Colonial Bank for Savings }\end{array}$ \\
\hline Iortheastern Mortgage & $\begin{array}{l}\text { First Mat'l Bank of } \\
\text { Louisville } \\
\text { Pirst Colonial Bank of } \\
\text { Louisville } \\
\text { Pirst Iat'l Bank of Boston } \\
\text { Banc Boston Leasing Inc. } \\
\text { Bank Tive for Savings }\end{array}$ \\
\hline $\begin{array}{l}\text { Resource Equity } \\
\text { Resource Pinancial Corp. } \\
\text { Resource Lending of } \mathbf{I l} \text {. } \\
\text { Resource Iortheast Inc. } \\
\text { Sterling Hortgage Co. }\end{array}$ & $\begin{array}{l}\text { Lincoln Irust Co. } \\
\text { Pleet Iat'l Bank } \\
\text { rleet lat'l Bank } \\
\text { Fleet lat'l Bank } \\
\text { Horcester County Inst. for } \\
\text { Savings } \\
\text { Baybank Middlesex }\end{array}$ \\
\hline $\begin{array}{l}\text { Sun Pinancial Group Inc. } \\
\text { The Resource Group Inc. }\end{array}$ & $\begin{array}{l}\text { Bank of Iew England (Dow } \\
\text { Fleet) Vorcester County } \\
\text { laples Federal S \& L Assoc. } \\
\text { Fleet Iat'l Bank }\end{array}$ \\
\hline
\end{tabular}

\section{Mortgage Company Lending Practices in Boston}

This section of the chapter on lending reviews the loan patterns of unregulated mortgage companies in Boston, Massachusetts. The general pattern of such activities is provided by unpublished research compiled by the Federal Reserve Bank of Boston. The general nature of this analysis, however, fails to completely assess the impact of unregulated mortgage company practices in minority neighborhoods. Therefore, for 
purposes of this study, these data were supplemented by unpublished data compiled by Union Neighborhood Assistance Corporation and were analyzed by this author.

FEDERAL RESERVE BANR STUDY OF MORTGAGE COMPANY LENDING PRACTICES Data Sources and Methodology

In response to the media coverage of the so-called second mortgage scam, the Federal Reserve Bank of Boston conducted research to document the total number of high-rate loans secured by real estate in suffolk County (95 percent of which is Boston). The focus of their research was on non-acquisition loans, meaning that no deed was transferred. These included second mortgage loans, first mortgages, and refinancing first mortgages (Munnell and Browne 1991).

The initial examination of mortgage company lending patterns presented in this chapter is based on the Federal Reserve study. The Federal Reserve research analyzed the number of high-rate loans originated by mortgage companies in Boston and compared that to the number of loans originated in Roxbury and Mattapan from 1987 to 1990. Data collection by the Federal Reserve researchers began with a review of Banker and Tradesman, a Boston publication that provides the name of the borrower, the property address, the lender and the amount of the loan. Terms of maturity and some interest rate information, not avallable from this source, were available at the Suffolk County Registry of Deeds.

Initial research by the Federal Reserve revealed that 51,223 such transactions had occurred between 1987 and 1990 (Munnell and Browe 1991). To simplify the research task, some assumptions were made by the 
Federal Reserve researchers. The local media had reported that the socalled scam was particularly prevalent in minority areas, so the first assumption made by the Federal Reserve researchers was that Roxbury and Mattapan would be appropriate neighborhoods for their research. Subsequently, the researchers' decision identified a number of mortgage companies active in these areas. A second assumption was made by the Federal Reserve researchers that if mortgage companies are not making high-risk loans in these areas, they are probably not making them elsewhere. Therefore, mortgage companies offering standard interest rates were omitted from the search. Thus, the research task became more manageable.

The next stage in the analysis by the Federal Reserve researchers was to define categories according to loan product terms and interest rates (Munnell and Browne 1991). Three such groups were defined:

1) Group 1 lenders offering typically short-term maturities (up to five years) with high interest rates (18-percent or more). These loans were defined as "very burdensome";

2) Group 2 lenders offering more manageable products with maturities from five to twenty years and interest rates of 15 - to 18-percent. The Federal Reserve researchers felt the Group 2 products offered flexibility and the opportunity to refinance if necessary;

3) Group 3 lenders offering products that are long-term (typically five to twenty years) with some moderately high interest rates (15- to 18-percent), and some conventional interest rates (under 15-percent).

4) Group 4 lenders offering conventional rates (under 15-percent) and conventional terms (typically up to twenty years).

These groupings, as defined, are used in subsequent analyses of this research project for purposes of clarity and continuity. 
The Federal Reserve researchers experienced difficulties, however, in examining the interest rates offered by mortgage companies as the Registry of Deeds records did not always include interest rates. Therefore, with companies that provided enough information to assume a pattern, such as Mortgage Funding Corporation, the Federal Reserve researchers categorized lenders according to that interest-rate pattern. Other companies, including Growth Mortgage Company and Chrysler First Eastern Financial Corporation, did not provide enough information to permit such assignments. Consequently, Growth Mortgage transactions were not included in the Federal Reserve analysis. It was also assumed by the Federal Reserve researchers that the companies were not high-rate lenders if their products were long term. This assumption applies to Chrysler First Eastern Financial Corp. Major Findings of the Federal Reserve Bank Study The following figures represent the number of loans and their geographic distribution. These figures were tabulated by the Federal Reserve researchers.

According to the Federal Reserve study, 698 loans were made throughout the city between 1987 and 1990 at interest rates in excess of 18-percent, most of which matured in less than five years (Table 4.3). An additional 1,630 loans were made with interest rates between 15- and 18-percent, but with longer maturity periods. The remaining loans were made with interest rates under 15-percent, or were unidentified (Munnell and Browne 1991).

While the number of high-interest loans in Roxbury and Mattapan total 207, this figure represents almost 30 percent of loans made 
throughout

Suffolk County.

Table 4.3 SUMMARY OF MORTGAGE COMPANY LOANS BY RATE, $1987-1990$

Additionally,

Dorchester has

not been

included in this

total, making it

impossible to

determine if

these products

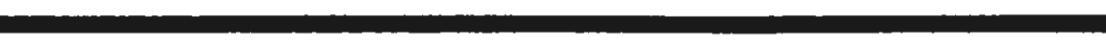

\begin{tabular}{ccc} 
Iotal Suffoll & loshury/ & lest of \\
Conttanus & Suffoll Conty \\
\hline
\end{tabular}

\begin{tabular}{lrrr}
$18 \%$ or vore & 698 & 207 & 491 \\
$15 \%$ to $18 \%$ & 1,630 & 298 & 1,332 \\
Under 15\% & 39,581 & 2,147 & 37,434 \\
Unidentified & 9,314 & 1,370 & $\frac{7,944}{47,201}$ \\
\cline { 2 - 2 } & 51,223 & 4,022 &
\end{tabular}

Source: Tederal Reserve Bank Heso to Dick Syron fros Alicia Munnell and Lyn Browne, Re: Second Hortgages in Suffoll County: 1987-90, Dated August 14, 1991. Tigures are estilates based on data fros Registry of Deeds and Banker \& Iradessan.

are specifically targeted to a geographic area or spread throughout the city using the data from the Federal Reserve study. Dorchester is located between Roxbury and Mattapan in the south-central area of the city.

The

Federal Reserve Bank study also categorized the lenders

according to

rates and terms.

Table 4.4 offers

a summary of the

number of

transactions by

lender group.
Table 4.4 SUMMARY OF MORTGAGE LENDERS, ROXBURY/MATTAPAN AND SUFFOLR COUNTY

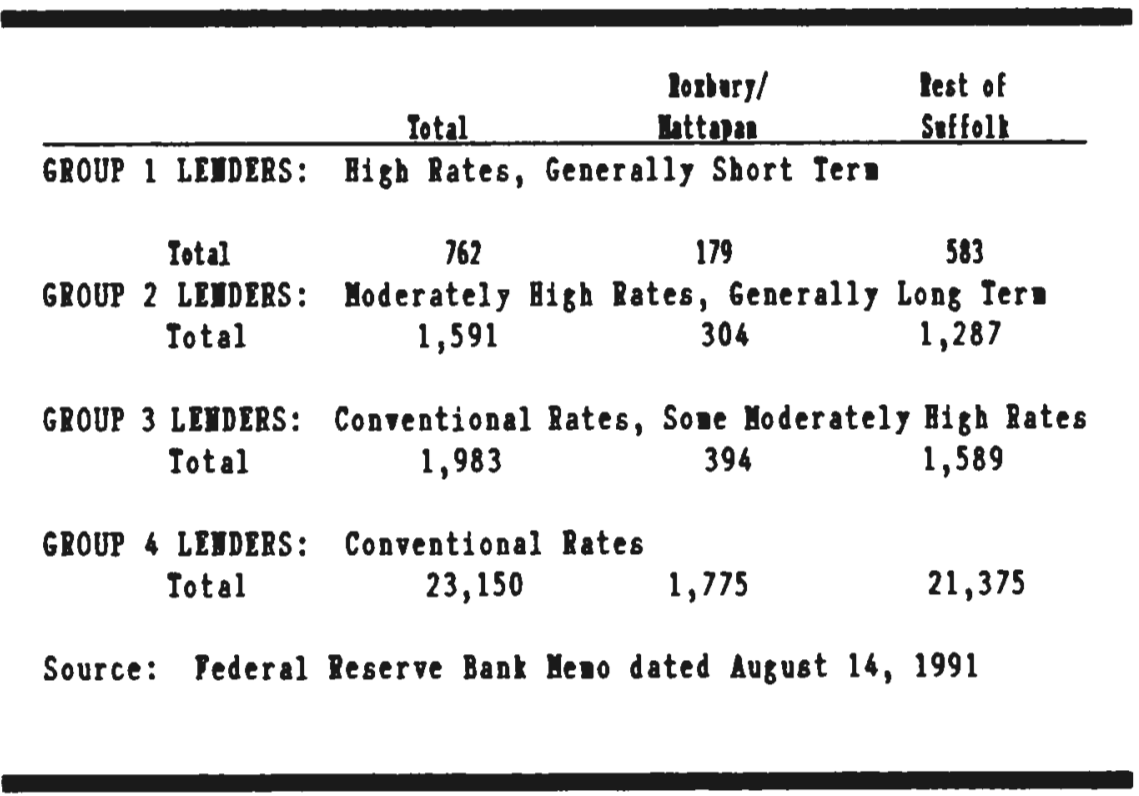


UNAC RESEARCH OF MORTGAGE COMPANY LENDING PRACTICES

Data Sources and Methodology

The review of Federal Reserve Bank data are supplemented in this project by unpublished data collected by Union Neighborhood Assistance Corporation (UNAC). UNAC researchers took a different approach than the Federal Reserve researchers in identifying the high-rate lenders.

UNAC researchers compiled a list of mortgage companies that offered products with high rates and short term maturities (Group 1 lenders by the Federal Reserve definition), or moderately high rates and longer term maturities (Group 2 lenders by the same criteria). UNAC researchers were able to verify the interest rates through examination of the actual loan agreements signed by victimized homeowners.

UNAC researchers brought the list of suspected mortgage companies to the Suffolk County Registry of Deeds. The Registry data base is capable of sorting by mortgage or loan grantee, that is, the institution or individual that holds a note on a property. This search identified all properties in Suffolk County that had a mortgage originated by the listed mortgage companies.

UNAC researchers then conducted a search of each property address in the Registry records to review all legal claims held on that property. Worksheets were completed on each owner-occupied property (investment properties were not included), recording each entry made by the Registry Clerk advising on the status of the property from 1985 to 1990, Including the street address of the property, the neighborhood (Roxbury, Dorchester, Jamaica Plain, etc.), the owmer's name, the date of the mortgage, the name of the mortgage company, code of the 
transaction, including actions taken by the mortgage company or the city such as a tax taking, and the book and page number. Unfortunately, the Suffolk County Registry of Deeds records do not contain information on Individual loan-to-value ratios, an important measure to determine an individual's ability to carry debt. The financial difficulties experienced by a household are revealed, in part, by the claims against the property.

This method produced detailed information on over 660 properties throughout Suffolk County. Data from the worksheets were useful in supplementing the Federal Reserve Bank data to create a more detalled account of mortgage company transactions, particularly the high-rate lenders.

UNAC and other community development organizations distributed a survey to the victimized homeowmers in the spring of 1992 . This action came in response to the state's Attorney General's request that UNAC provide details of the loan agreements made by hardlenders. Thirty-four surveys were made available to this author as a sample of the victimized homeowners. Information on contractors was included in the surveys, as well as income and household debt.

\section{ANALYSIS OF MORTGAGE COMPANY LENDING PATTERNS BY THIS AUTHOR} Methodology and Data Sources

The UNAC worksheets were made available to this author by Bruce Marks, UNAC Executive Director. Because the worksheets listed the claims against the properties contained little analysis, the data could be reviewed without preconceived opinions regarding the status of the properties. This author first sorted the property addresses by 
neighborhood. Each property was then categorized through the use of indicators to reflect the approximate risk to the property owner. Indicators included foreclosure notices, evidence of possession, and attachments or liens on property. A complete list of the groupings and indicators are presented below. Th1s manner of organizing the data facilitated examination of the consequences to homeowners who contracted with high rate mortgage companies. The groups included:

Group A: the original owner still owned the howe, and there were no indicators of financial difficulties, such as an attachment or levy (lien) or tax lien against the property.

Group B: the original owner still owned the home, but indicators of financial difficulties were evident. Indicators included attachment, levy (lien), tax lien, evidence of possession, order notice of foreclosed mortgage, or notice petition of foreclosed tax.

Group C: the property had changed hands either by foreclosure or by deed, following an order notice of foreclosed mortgage or a notice petition of foreclosed tax.

Group D: the property had changed hands through sale by owner. The worksheets were also used to analyze the number of loans attached to each property. This was achieved by simply counting the mortgage companies and other lenders recorded for each property by the Registry of Deeds.

This author experienced the same difficulty in determining the Interest rates as the Federal Reserve researchers, as disclosure information was not required and little information was available from Registry records. The Registry of Deeds data on interest rates are supplemented by a review of court cases. 
Further Analysis of Mortgage Company Lending Patterns

The Dorchester information was obtained from the UNAC worksheets. Two Group 1 mortgage companies (1.e. short maturities, high interest rates) have been particularly active in Roxbury, Dorchester and Mattapan. The companies are the Resource Companies (including all loans originated under the owner's various names) and Growth Mortgage. It is interesting to note that the Federal Reserve study did not include Information on Growth Mortgage in any of its lender categories. Information that was available on this company from interviews by UNAC with affected homeowners indicated that the loans were balloon payment debts. Registry of Deeds records demonstrate that foreclosure notices were issued on many properties approximately one year after contracting the loan. Growth Mortgage was included in the Group 1 category of lenders as it appears to meet the defined criteria.

The Resource Companies contracted a total of 336 loans in Dorchester, Roxbury and Mattapan. This figure is higher than the Federal Reserve Bank total of 232 because the Federal Reserve study covered the period from 1987 to 1990, while the UNAC research began in 1985 and continued through 1990. Of the total 336 loans, Resource made 192, or 57.1 percent of its loans in Dorchester, 38, or 11.3 percent in Roxbury, and 61, or 18.2 percent in Mattapan. Combined, this indicates that 86.6 percent of their lending activity throughout all of Suffolk County is distributed in the three neighborhoods analyzed in this research project.

Growth Mortgage followed the lending pattern of the Resource Companies. A total of 98 loans were made throughout Suffolk County, 
with 59, or 60.2 percent in Dorchester, 14 , or 14.3 percent in Roxbury, and 9, or 9.2 percent in Mattapan. These figures suggest that Dorchester has experienced a higher proportion of Group 1 lender products than all other neighborhoods combined.

For comparison, the authors of the Federal Reserve study tabulated the total number of loans made at less than 15-percent interest rates in Roxbury and Mattapan at 2,147, which represents 5.4 percent of the total throughout the city. The citywide average of all loans with traditional interest rates issued by mortgage companies represents over 77 percent. These figures suggest there is a real disparity in the lending practices of mortgage companies in different neighborhoods throughout the city. Number of Loans per Property

The preceding figures have focused on the loan types and their neighborhood distribution. The following analysis concentrates on the properties and the number of loans attached to each. These data are compiled from the worksheets collected at UNAC.

The sample size for analysis is 269 properties contracted with Group 1 lenders. The Federal Reserve study states the Suffolk County total is 762. The sample size is believed to be large enough to offer an accurate representation of Group 1 lender patterns.

Typical banking industry standards provide that no more than two loans be attached to a property (Couture 1992). Generally, these would include the first mortgage and a second "equity" loan, a product that became popular during the 1980s. Equity loans have replaced fixed-rate home improvement loans, in that the interest rates generally vary, 
usually one or two interest points over the prime interest rate. Banks adjust interest rates accordingly, reducing their risk (Couture 1992).

Analysis of Table 4.5 NUMBER OF MORTGAGES ON PROPERTIES

the sample

properties leads to

the conclusion that

the majority of

properties in

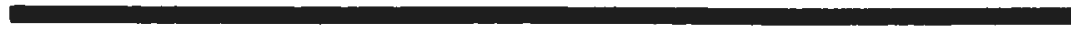

\begin{tabular}{|c|c|c|c|c|c|c|}
\hline \multirow{2}{*}{\multicolumn{4}{|c|}{ Dorchester Roxbury }} & \multicolumn{2}{|c|}{ lattapan } & \multirow[t]{2}{*}{ Otbers } \\
\hline & & & & to $\mathrm{Pr}$ & operties & \\
\hline $1-2$ & $3+$ & $1-2$ & $3+$ & $1-2$ & $3+$ & $1-2 \quad 3+$ \\
\hline
\end{tabular}

Source: Property records, Soffoll Cousty Pegistry of Deeds

Dorchester, Roxbury and Mattapan had over three loans attached to them (Table 4.5). Dorchester data alone produced 150 properties for analysis. Of these, 62 properties had one or two loans, and 88 had three or more, many of which had five or six loans, and two properties had eleven loans attached. Of the total properties throughout the county under contract with Group 1 lenders, 42.4 percent of the sample satisfied banking standards, with one or two mortgages, while 57.6 percent exceeded (i.e. did not meet) the two-loan maximum industry standard.

\section{Interest Rates}

Determining the interest rates contracted with the Group 1 lenders was difficult. This industry had not been regulated, and mortgage companies were not required to make such information public. The property records of the Suffolk County Registry of Deeds offer some interest rate information. The following list, compiled through a review of the court case, the Commonwealth of Massachusetts v. Resource Companies, offers an example of information that is avallable on the Resource Companies: 
Property at 848 Huntington Ave., Boston. Amount financed: $\$ 6,751$, annual interest rate: 39.45 -percent, finance charge: $\$ 5,327.28$, total payments due: $\$ 12,078.28$

Properties at 14 and 16 Abbott St., Dorchester. Amount Financed: $\$ 30,800$, annual interest rate: 34.09-percent, finance charge: $\$ 21,000$, total payments due: $\$ 51,800$

Property at 9 Mt. Bowdoin Terrace, Dorchester. Amount financed: $\$ 30,800$, annual interest rate: 34.09 -percent, finance charge: $\$ 21,000$, total payments due: $\$ 51,800$

Property at 18 Mascot St., Dorchester. Amount financed: $\$ 10,750$, annual interest rate: 33.68 -percent, finance charge: $\$ 7,242.68$, total payments due: $\$ 17,992.68$

Property at 22 Rutland St., Boston. Amount financed: \$56,082.16, annual interest rate: 30.86-percent, finance charge: $\$ 34,618.32$, total payments due: $\$ 90,700.32$

Property at 40 Oak St., Hyde Park. Amount financed: \$6,830, annual interest rate: 42.09-percent, finance charge: $\$ 5,750$, total payments due: $\$ 12,580$

Property at 82 Rosewood St., Mattapan. Amount financed $\$ 18,100$, annual interest rate: 31.77-percent, finance charge: $\$ 11,500$, total payments due: $\$ 29,600$

Rates above 24-percent interest are usurious by industry standards (Couture 1992). The courts, as well, have found the rates to be exceptionally high. A summary of the court charges will be offered in the Chapter Five.

The burden these loans impose on homeowners can be seen in the number of foreclosures that have occurred in Roxbury, Dorchester and Mattapan. Of 348 properties analyzed, 147, or 42.2 percent, were classified as Group C, the homeowmers lost their homes either by foreclosure or deed. Another 97, or 27.9 percent, were classified as Group B, evidence of financial difficulties are evident and homeowmers are at risk of losing their properties. Only 57 properties, or 16.4 percent show no evidence of losing their homes (Group A), and 47, or 
13.5 percent, have sold their homes (Group D). These data indicate the lending practices by mortgage companies have had a destabilizing effect on both the residents and the neighborhoods.

Contractor Lending Practices

The media covering of the second mortgage scam reported that contractors were often working with mortgage companies, and acted as loan originators in obtaining borrowers' signatures on the loan applications. This scenario was also offered in the public presentation by Diane Modica, Commissioner of Consumer Affairs and Licensing, City of Boston, in Mattapan on June 24, 1991 that this author attended. Very little information on contractors was found in the search through the Registry of Deeds records.

Review of Registry records indicated a total of nine liens altogether were attached to properties in the 660 city-wide records reviewed. U.S. Window Corp. had four property liens, three of which were on properties located in Dorchester and one in Jamaica Plain. Vinyl Distributors of New England, Inc. had a lien against one property in Dorchester, as did NewPro, Inc., New England Brickmaster, Inc., Boston Bullding and Remodeling, Inc., and Elan Window Corp.

Additional information on contractors was obtained from surveys completed by the victimized homeowners. A sample of thirty-four surveys were analyzed by this author. Fighteen surveys stated the second mortgages were taken for home repairs, sixteen surveys stated the second mortgages were taken for refinancing, debt consolidation, or such personal concerns as college tuition payments. 
Survey responses indicated that half of the loans taken for home 1mprovements resulted in unsatisfactory construction. Substandard conditions included leaking roofs, unsafe stairs and/or porches, heaters that were not working, and windows that were not air tight. Three respondents stated no improvements were completed, and the contractors had been paid for the work. The contractor companies against whom the complaints were made include U.S. Window Corp., Seacoast Industries, Inc., City Home Improvement, and Commonwealth Thermal Products. Violations of Truth-In-Lending Requirewents

The borrowers were questioned in the survey to determine if they had completed the loan application, or if the application was completed by the loan originator. Survey questions asked if the borrowers were informed of the conditions of the loan, including the interest rates, the length of the loan, the amount of closing costs, prepayment penalties, and the condition of balloon payments. Twenty-three of the thirty-four respondents answered these questions. Of the twenty-three respondents, twelve stated the loan applications were completed for them, while eleven borrowers completed the applications themselves. Only one respondent stated that the loan originator made a full disclosure of the conditions of the loan. In most cases, partial information was offered by the loan originator. The balloon payment at the end of the term was the most common piece of information not disclosed, followed by the amount of closing costs and pre-payment penalties. These data suggest that truth-in-lending laws are commonly violated by the loan originators. 
Household Income Information

Household income levels were also stated in the surveys. Almost all of the households that were shown in the samples earned approximately $\$ 20,000$ annually, suggesting that most were probably not in a position to successfully carry the debt incurred by contracting wth the hardlenders. Three households earned between $\$ 30,000$ and $\$ 40,000$, and one household earned $\$ 75,000$ annually. It has not been possible to confirm the individuals credit history due to confidentiality laws.

\section{SUMMARY OF MORTGAGE COMPANY LENDING PRACTICES}

The objective of this chapter was to answer the major questions, What finance structure enables unregulated mortgage companies to operate; and, who are the unregulated lenders in violation of established lending standards, and in what neighborhoods do they operate? Review of recent literature suggests that mortgage companies operate through a line of credit extended by major banks. Analysis of Suffolk County Registry of Deeds records described the lending practices of several mortgage companies offering very burdensome loan products in Roxbury, Dorchester and Mattapan. Information on the geographic distribution of mortgage companies was offered, indicating that mortgage companies operate in the specific neighborhoods redlined by banks. The number of loans, and the number of loans attached to properties were offered, indicating that many households incurred more debts than the banking industry standards suggest. What information is available on the terms and interest rates of the loans were offered as well, many of which do not satisfy banking industry standards. 
Additional information was offered on some on the contractors that have provided home improvements at various levels of completion and satisfaction. Little information is available on this group from the data sources. Perhaps this question should be the focus of another research project using different data sources, such as the records of the Better Business Bureau or records maintained by the Office of the Commission of Licensing and Consumer Affairs.

Responses to a sample of surveys completed by victimized homeowners suggest that violations of truth-in-lending laws was a common practice of the Ioan originators of Boston-based mortgage companies. This information, however, must be classified as anecdotal as the actual contracts signed by the borrowers were, in most cases, not made available.

Chapter Five will review the efforts of the city of Boston and community groups to seek an equitable resolution to the unfair practices that have occurred in the city's minority neighborhoods. 
CHAPTER FIVE

EFFORTS TO REMEDY THE

"SECOND MORTGAGE SCAM" 
THE CITY RESPONDS TO THE "SCAM"

Mortgage companies have met the demand for mortgage and home improvement financing, but have done so through the use of products that are unacceptable by banking industry standards. Community groups and activists brought the lending practices into the public awareness through the media, and the city of Boston has responded by attempting to seek an equitable resolution to the problem.

One of the first and most effective remedies was to regulate mortgage companies in Massachusetts. The new regulation is Massachusetts General Law 255E that became effective on January 1, 1992. Under the provisions of the new law, mortgage companies must maintain a $\$ 100,000$ net worth, while contractors are allowed to post a bond for this amount. Rate and term disclosure requirements are included, administered by the Massachusetts Banking Commission. Temporary licenses have been given to existing mortgage companies while they are investigated by the Banking Commission. At the time of this writing, thirty-three mortgage company licenses have been suspended for noncompliance with the regulation.

An incentive to the banking industry had been their ability to use loans originated by mortgage companies in minority neighborhoods as credit toward their CRA responsibilities. H.6021, An Act to Further Regulate Mortgage Lending, addressed this issue. The state CRA, Section 14, Chapter 167, had allowed a bank that buys loans from a high interest lender or that provides financing to such a lender to receive positive CRA credit. The new law, H.6021, reduces this credit, and also caps interest rates. 
The Attorney General imposed a moratorium on foreclosures by mortgage companies suspected of charging usurious interest rates. A reinvestment program is currently being developed to seek an equitable remedy for those homeowners affected by mortgage company lending practices. It is proposed that mortgage company loans be reviewed to determine the amount of the loan. Standard interest rates would be applied to that amount, the additional fees will be eliminated, and the borrower would be responsible for only the amount borrowed at standard rates. The details of this program, of course, are not yet available, as the Attorney General is currently collecting the data necessary to conduct such an analysis.

Banks have come forward to provide needed funds to minority communities as well. Shawmut Bank has provided $\$ 5$ million through the Massachusetts Housing Partnership to provide relief for victims of usurious interest rates and to create a pool for first-time buyers in minority neighborhoods. Baybank is expected to contribute several million dollars, and Fleet, which had extended a line of credit to the Resource Companies (the largest high rate lender in Roxbury, Mattapan and particularly Dorchester), has provided some $\$ 65$ million to the city of Boston and a housing development program it administers. An additional $\$ 30$ million has been provided by Fleet through its Bank of New England (BNE) purchase and prior commitments of BNE.

Charges have been brought against the some of the hardlenders. The Commonwealth of Massachusetts brought charges against Home Repair, Inc., formally Seacoast Industries, Inc., and Robert Finestone for unfair and deceptive acts and practices in the sale of home improvement 
services and in the provision of mortgage and other loan services in connection with financing home improvements services. These acts are in violation of the Massachusetts Consumer Protection Act., G.L. Chapter 93A, Section 2 (A).

The Commonwealth of Massachusetts also brought charges against Resource Financial Group, Inc., Resource Lending, Inc., and Resource Services, Inc., all of 175 Derby St., Hingham, MA. The charges included unfair and deceptive acts and practices in violation of the Massachusetts Consumer Protection Act, and charges that the companies engaged in oppressive and unconscionable acts or practices. Such acts included charging full interest rates made to customers on funds held by Resource as "security funds or deposits" without providing any use or benefit to the customers for the use of these funds, and for charging such interest on the security funds as to be oppressive and unconscionable. Additional charges were brought against Resource Companies for violating truth-in-lending laws. Hopefully, these court cases will discourage mortgage companies from engaging in unfair lending practices in the future.

Bank regulators have agreed to assert their authority and require banks to meet their CRA responsibilities as well. It is assumed that if the demand for home financing is met by traditional sources, the need for alternative financing will be reduced. 
CHAPIER SIX

CONCLUSIONS 


\section{CONCLUSIONS}

This author described the lending practices of banks and mortgage companies in the selected Boston neighborhoods of Roxbury, Dorchester and Mattapan. Because city officials and community groups are currently seeking remedies to solve the problems of usurious lending practices by unregulated mortgage companies, this research project cannot address all the issues involved with the lending structure in place in Massachusetts. Nonetheless, these findings provide a base-line of information to assist other researchers in subsequent investigations.

The evidence presented in this report indicates that the regulated banking industry has not met the needs of low- and moderate-income neighborhoods in Boston as required by the CRA. Even with adjustments for wealth and income, it is evident that neighborhoods with a majority of black residents have been redlined by the banking industry. The resulting credit crunch in Roxbury, Dorchester and Mattapan has created a demand that was met by unregulated mortgage companies.

No attempt was made by this researcher to determine if mortgage company products were marketed specifically to residents in the subject neighborhoods. However, it seems more than coincidence that the usurious mortgage companies would market the highest proportion of their products in precisely the same neighborhoods that the banks have redlined. Whether by coincldence or design, the equity lending practices of these mortgage companies were found to adversely affect disproportionate numbers of poor black residents in Roxbury, Dorchester and Mattapan. 
The author determined that subject mortgage companies operated through financial relationships with banks. Some, particularly the Resource Companies funded by Fleet Bank, packaged loan products that were very burdensome to borrowers. A result of this practice was often foreclosure.

This practice has a destabilizing effect, and promotes the deterioration of the housing stock within neighborhoods. The predictable pattern of deterioration established by the Urban League suggests that Roxbury, Dorchester and Mattapan are currently in the third or fourth stage of housing transition. That is, there is evidence of property speculation and exploitation (Stage 3), and deterioration of market conditions and disinvestment by both financial institutions and property owners who stop maintaining the property (Stage 4). Evidence of the final stage, property abandonment, can already be seen in certain parts of Roxbury.

Other findings described in this study are as follows:

- Attempts have been made by Boston city officials and local community groups to seek a resolution to the financing problem. A multi-million dollar fund has been established by the Fleet/Norstar Group, Shawmut Bank and Baybank for the purposes of home purchases and home repair financing in Roxbury, Dorchester and Mattapan.

- A moratorium on foreclosures has been put in place by the Attorney General to provide a period of time to review the loan contracts. Community groups are advocating that traditional terms and interest rates be applied to these loans, reducing the burden to the borrowers.

- Mortgage companies became regulated in Massachusetts on January 1, 1992. Temporary licenses have been issued to existing mortgage companies while the Massachusetts Banking Commission investigates the solvency and business practices of the mortgage companies. At the time of this writing, thirty-three companies have had their ilcenses suspended because they have not met the new regulations. 
- Finally, those individuals who have abused the unregulated environment and violated consumer protection laws have had complaints charged against them by the Commonwealth of Massachusetts. Several individuals have been convicted and are currently serving $j a 1 l$ sentences.

\section{RECOMMENDATIONS}

These findings show that Boston's major banks have not wet the needs of low- and moderate-income residents as required by the Community Reinvestment Act. The economic recession of the early 1990s makes it doubtful that this situation will change in the near future without strict enforcement by bank regulators. Additionally, the current structure of the banking industry, and the recent expansion of wholesale mortgage banks that purchase loans originated by mortgage companies provides evidence that mortgage company activities will continue to grow in the future. If regulated banks continue to place their resources into loan purchases rather than branch offices, community needs will likely remain unmet. The current status of the industry policing itself does not appear to be effective. Perhaps it is time to place CRA enforcement requirements beyond the banking industry.

The current structure of the banking industry allows abuse which may well continue in the future. Mortgage companies do not replenish their funds through deposits in the same manner as banks. Mortgage companies are able to offer loans through a line of credit they maintain with banks. Home loans originated by mortgage companies are sold back to banks that, in turn, sell many of the mortgages in the secondary mortgage market. The banks purchasing these mortgages do not review all applications in the same manner they would if they originated the loans. Bank examiners select a few loans as a sample for review, but complete 
information on interest rates, especially over 18-percent, has not always been provided by the mortgage company (Marantz 1991). Those mortgages sold in the secondary mortgage market that default are insured by the federal government. Under this structure, banks enjoy an insulated position. They have not been held responsible for usurious lending practices because the mortgage companies originated the loans. Loans sold in the secondary mortgage market and subsequently default are insured by the federal government. It appears that the banks have little to lose in this situation.

In the interests of economic stability, it is desirable to financially support the banking industry against major losses. Yet this author believes that the taxpayer has a right to expect banks to promote industry standards in return for the safety net the federal government provides the banking industry. This includes meeting the obligations of the Community Reinvestment Act to provide products and services to lowand moderate-income households, as well as reviewing the loan applications originated by mortgage companies.

If banks were to be held culpable for the destabilizing effect that, in fact, they are promoting by financially supporting the hardlenders, it seems likely they would review the loan contracts more thoroughly as they purchase the loans from mortgage companies. Banks could simply refuse to purchase questionable mortgage company loans. Such efforts would serve to promote industry standards and prevent usurious interest rates and the subsequent foreclosures that result from very burdensome debts. These efforts might serve to reduce the number 
of future foreclosures and might add a few jobs to the local economy as well.

A few of the mortgage companies operating in Roxbury, Dorchester and Mattapan have abused the unregulated environment. Recent legislation, however, serves to provide safeguards for borrowers in the future. Perhaps Congress should consider regulating mortgage companies operating throughout the United States to prevent future abuse of the unregulated environment.

As of this writing, the residents of Roxbury, Dorchester and Mattapan are still without a steady supply of funds for the purchase and improvement of homes. As previously mentioned, Shawmut Bank, Baybank and Fleet/Norstar Group have recently established a multi-million dollar fund to meet the neighborhood needs. This seems to be a short-term solution, however. One wonders if the fund will be replenished when the original monies are disbursed, or if the neighborhoods will be left to deteriorate once again. The future stability of the area requires a steady flow of capital. FUTURE RESEARCH

This investigation stimulates questions for future research. For example, many of the residents of Roxbury, Dorchester and Mattapan are low-income households. For some, the costs of homeownership might be too burdensome to establish homeownership as a goal. But, for those homeowners who purchased their homes twenty or thirty years ago, and have carefully managed their resources to maintaln their property, what programs need to be made available and/or expanded to these individuals? Programs for consideration might include reverse equity plans, or low- 
interest home Improvement loans which can provide needed capital to homeowners with less risk of foreclosure.

Finally, it would be of interest to learn the extent to which victimized homeowners were helped by state or federal programs to enable them to become homeowmers in the first place. Historically, such home purchase programs have been established without concern for continuing maintenance responsibilities. Information about the needs of assisted households could lead to recommendations for ongoing support for lowand moderate-income homebuyers/owners. Within this context, it would also be of interest to learn the costs associated with a long-term government commitment to low- and moderate-income homeowners. It would be useful to compare the costs of such support programs against the costs to the taxpayer for mortgages in default because of very burdensome debts. While these questions are beyond the scope of this research, determining the answers might help to solve some of the problems of housing in Boston. 


\section{GLOSSARY}

Hardlenders: A colloquialism used by the Boston media and community organizers to refer to the mortgage companies packaging loan products that are typically short-term, very high interest rate debts. The term differentiates these lenders from other unregulated mortgage companies whose products are less burdensome to borrowers.

Regulated Banks: This term refers to financial institutions that are regulated by one or more of the four regulatory agencles, the Federal Reserve, the office of the Comptroller of the Currency (OCC), the Federal Deposit Insurance Corporation (FDIC), and the Federal Home Loan Bank Board (FHLBB). Lenders under the jurisdiction of these agencies include all banks, savings and loans, and credit unions that provide home mortgage loans.

Unregulated Mortgage Companies:

Refers to mortgage companies operating in an unregulated environment. Most such mortgage companies offer loans to borrowers through a line of credit established with regulated banks. Although a few unregulated mortgage companies are large enough to remain independent of banks and sell their loans directly into the secondary mortgage market, most rely on the financial relationship with banks.

Usurious Interest Rates:

Are defined as interest rates in excess of 24-percent annually.

Usurious Lenders: Are those lenders charging interest rates in excess of 24-percent annually.

Usury:

The act or practice of lending money at an exorbitant or illegal rate of interest. 


\section{REFERENCES}

Books

Achtenberg, Emily Paradise and Peter Marcuse, "The Causes of the Housing Problem", Critical Perspectives on Housing, ed Bratt, et al, Temple University Press, 1986

Apgar, William C., Denise DiPasquale, Jean Cummings, and Nancy McArdle, The State of the Nation's Housing 1991, Joint Center for Housing Studies at Harvard University

Arrow Street Map Atlas of Metropolitan Boston MA 1978

Citizens Commission on Civil Rights "The Federal Government and Equal Housing Opportunity: A Continuing Failure" Critical Perspectives on Housing ed. Bratt et al 1986

Commonwealth of MA v. Resource Financial Group, Inc., Resource Lending, Inc., Resource Services, Inc. West Publications

Commonwealth of MA v. Home Repair, Inc., formally Seacoast Industries, West Publications

Finn, Charles Mortgage Lending in Boston's Neighborhoods, 1981-1987: A Study of Bank Credit and Boston's Housing, December, 1989

Florida, Richard, "Overview", Housing and the New Financial Markets 1986

Listokin, David and Stephen Casey, Mortgage Lending \& Race: Conceptual and Analytical Perspectives of the Urban Financing Problem 1980

McAfee, Rathy "Socialism and the Housing Movement: Lessons from Boston" Critical Perspectives on Housing ed Bratt et al 1986

Meyerson, Ann "Housing Abandonment: The Role of Institutional Mortgage Lenders" Critical Perspectives on Housing ed Bratt et al 1986

Meyerson, Ann "Deregulation and the Restructuring of the Housing Finance System" Critical Perspectives on Housing ed Bratt et al 1986

Olson, David A., "Mortgage Markets in the Year 2000, Overview", Journal of Housing Research, Vol. 1, Issue 1, 1990

Rose, Peter and Richard L. Haney Jr., "The Players in the Primary Mortgage Market", Journal of Housing Research, Vol. 1, Issue 1, 1990

Stone, Michael "Housing and the Dynamics of U.S. Capitalism" Critical Perspectives on Housing ed Bratt et al 1986 


\section{Periodicals}

American Banker, "Top Numbers 1989 Update" 1989 p64

Canellos, Peter, "Probe Asked of Fleet Finance's Practices", Boston Globe, June 9, 1991

Bradbury, Ratharine, et al, "Geographic Patterns of Mortgage Lending in Boston, 1982-1987", New England Economic Review, Federal Reserve Bank of Boston, Sept.-Oct. 1989

Federal Reserve Board, Comptroller of the Currency, Federal Home Loan Bank Board, Federal Deposit Insurance Corporation, "Joint News Release on CRA" March 12, 1989

Marantz, Steve, "Roles in Mortgage Schemes Scrutinized", Boston Globe, May 31, 1991

\section{Interviews}

Couture, Paul, Director of Major Assets, FDIC, telephone interview by author April 1992

Marks, Bruce, Executive Director, Union Neighborhood Assistance Corp., Local 26, Hotel and Restaurant Workers, Boston MA, several interviews by author in June, July, and December 1991, and January through April, 1992

Massachusetts Banking Commission, Legal Department, telephone interview by author, April, 1992

Walker, Richard, Director of Community Relations, Federal Reserve Bank of Boston, telephone interview by author, February 1992

\section{Others}

Case, Rarl "Housing Finance in Boom and Post-Boom Markets", The Banking Crises and the Future of Housing, A Fannie Mae University Colloquium Series, Oct. 17, 1991

Ferguson, Thomas "Housing and the Internationalization of the U.S. Banking Industry", The Banking Crises and the Future of Housing, A Fannie Mae University Colloquium Series, November 14, 1991

Munnell, Alicia and Lynne Browne, Memorandum to Dick Syron, Federal Reserve Bank of Boston, August 14, 1991

Suffolk County Registry of Deeds records for properties in Roxbury, Dorchester and Mattapan, 1985-1990 